\title{
Genetic engineering of apple (Malus domestica Borkh.) for resistance to fungal diseases using g2ps1 gene from Gerbera hybrida (Asteraceae)
}

\author{
Ali Bacha N.M. ${ }^{1}$; Batha M. \& Abdul Kader A.M. ${ }^{*}$ \\ ${ }^{I}$ General Commission for Scientific Agricultural Research (GCSAR), Biotechnology Department, Douma, P.O. \\ Box 113, Damascus, Syria. Fax : 00963-11-5744053/575 7992; \\ ${ }^{2}$ Damascus University, Faculty of Agriculture, Department of Horticulture, Damascus, P.O. Box 30621, Syria
}

\begin{abstract}
Summary: In the present study, $g_{2} p s_{1}$ gene from Gerbera hybrida coding for 2-pyrone synthase which contribute for fungal and insect resistance was used. The aim was to work out an efficient approach of genetic transformation for apple cvs. 'Golden Delicious', 'Royal Gala' and 'MM111', 'M26' rootstocks for improving their fungal resistance using genetic engineering techniques. Adventitious shoot formation from leaf pieces of apples studied was achieved using middle leaf segments taken from the youngest leaves from in vitro-grown plants. Optimum conditions for , direct' shoot organogenesis resulted in high regeneration efficiency of $90 \%, 95 \%, 92 \%, 94 \%$ in the studied apples

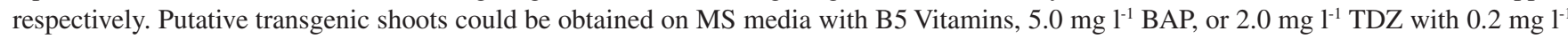
NAA in the presence of the selection agent "PPT" at 3.0-5.0 $\mathrm{mgl}^{-1}$. Shoot multiplication of transgenic shoots was achieved on: MS + B5 vitamins + $1.0 \mathrm{mg} \mathrm{l}^{-1} \mathrm{BAP}+0.3 \mathrm{mg} \mathrm{l}^{-1} \mathrm{IBA}, 0.2 \mathrm{mg} \mathrm{l}^{-1} \mathrm{GA} 3+1.0 \mathrm{~g} / \mathrm{l} \mathrm{MES}+30 \mathrm{~g} / \mathrm{l}$ sucrose $+7.0 \mathrm{~g} / \mathrm{l}$ Agar, with the selection agent PPT at 5.0 $\mathrm{mg} \mathrm{l}^{-1}$ and were subcultured every 4 weeks in order to get sufficient material to confirm transformation of the putative shoots obtained. Six, seven, one and six transgenic clones of the apples studied respectively have been obtained and confirmed by selection on the media containing the selection agent "PPT" and by PCR analysis using the suitable primers in all clones obtained for the presence of the selection" bar gene (447 bp) and the gene-of- interest " $g 2 P S 1$ " (1244 bp), with transformation efficiency of $0.4 \%, 0.6 \%, 0.1 \%$ and $0.3 \%$ respectively. These transgenic clones were multiplied further in vitro in the presence of the selection agent 'PPT' and rooted in vitro. Rooted transgenic plantlets were successfully acclimatized and are being kept under-containment conditions according to the biosafety by-law in Syria to evaluate their performance for fungal resistance.
\end{abstract}

Abbreviations: BAP, N6-benzylamino-purine; IBA, Indole-3-butyric acid; GA3, Gibberelic acid; MES, 2-(N-Morpholino) Ethanesulfonic acid; MS, Murashige and Skoog medium (1962); NAA, a-naphthalene acetic acid; PPT, Glufosinate-amonnium Pestanal ® (Riedel-de Haen); TDZ, Thidiazuron (N-phenyl-N-1,2,3-thiadiazol-5-yl urea), GD, apple cv. Golden Delicious; RG, apple cv. Royal Gala

Keywords: Agrobacterium tumefaciens, Genetic transformation, $g_{2} p s_{1}$ gene, Gerbera hybrid, In vitro culture, Organogenesis

\section{Introduction}

Apple (Malus domestica Borkh.) is one of the most important fruits in temperate zones with a total world production amounted to 76.3 million t/year in 2012 (FAO, 2012). Conventional breeding of apple is very long term and cannot reproduce the desirable qualities of our best commercial varieties and rootstocks. However, genetic transformation is a key process to sustain its demand by permitting the potential enhancement of existing cultivars as well as the development of new cultivars resistant to pests, diseases, and storage problems that occur in the major production areas (Polanco et al. 2010). It offers an attractive alternative to conventional breeding for the creation of resistant varieties since it is faster, can use genes from many sources, and will preserve the desirable qualities of the transformed variety or rootstock. (Aldwinckle et al. 2000).
On the other hand, genetically modified (GM) crops have gained ground on their conventional counterparts. Biotech crop hectares increased by an unprecedented 100-fold from 1.7 million hectares in 1996, to over 170 million hectares in 2012. Of about 1.5 billion hectares of arable land worldwide, about $12 \%$ were used to plant GM crops in 2012 (James 2013).

Gene transfer manipulations are used for genetic modification of important characters in apple such as resistance to diseases. Some of these studies included the chosen variaties and rootstocks in the present work. These included genetic transformation of Royal Gala (Hyung et al. 1995, Liu et al. 1998, 2001; DeBondet et al. 1994, 1996; Norlli et al. 1999, Schaart et al. 1995, Puite and Schaart 1996; Yao et al. 1995; Faize et al. 2003, 2004; Liu et al. 1998, 2001), Golden Delicious (Schaart et al. 1995; Puite and Schaart 1996; Maximova et al.1998), M26 (Norlli et al. 1994; 
Welander et al. 1998; Holefors et al. 1998, 2000), while no single study was published on genetic transformation of the apple rootstock MM111. However, the traiats expressd in transformation of these apples included: resistance to fire blight Erwinina amylovora in M26 (Norelli et al .1994, ko et al. 2000, Aldwinckle et al. 2003; Hanke et al. 2000; Abdul -Kader et al. 1999, Aldwinckle et al. 2003; Malony et al. 2007a); Royal Gala ((Liu et al. 199, 2001), insect resistance in RG (Markwic et al. 2003), fungal resistance in M26 (Markwic et al. 2003; Xue et al. 2008; Holfors et al. 2000), RG (Artlip et al. 2007), Color modification in RG (Espley et al. 2007), Modified metabolism in RG (Hrazdina et al. 2003), Cell adhesion in RG (Alkinson et al. 2002), Promoter studies in RG and M26 (Malony et al. 2006), M26 (Norelli et al. 2007), Selectable markerstudies in M26 (Zhu et al. 2004, Malony et al. 2007 b). On the other hand, development of an effective system for gene transfer in the different Rosaceae species depends largely on the availability of tissue culture techniques that permit regeneration of shoots, selection of transformants, and propagation of transgenic plants. Increasing leaf regeneration efficiency is critical for the development of a transformation system in the Rosaceae family using an Agrobacterium tumefaciens vector or by biolistic process (Aldwinckle and Malnoy 2009).

g2ps 1 gene codes for 2- pyrone synthase (2ps) from Gerbera hybrida (Helariutta et al. 1995). The expression of this gene is suitable for the manipulation of the phytoalexin spectrum. The Chalcone Synthase -2 gene was previously considered as an unusual member of a chalcone synthase (CHS) gene family in the ornamental plant Gerbera hybrida (Asteraceae). GCHs gene utilizes acetyl-coA and 2-malonylco-A for the biosynthesis of two types of 6-Methyl-4-hydroxy2-pyrone derivatives, 'gerberin' and 'parasorboside', which contribute for insect and fungal pathogen resistance as well as medical interest. Later, the GCHS2 gene was renamed as the $g 2 p s 1$ gene based on its function associated with 2-pyrone Synthesizing.

Because of the high susceptibility to fungal diseases of the most important commercial apple cultivars and rootstocks, genetic transformation has been one good method for the development of resistant cultivars. Therefore, the aim of the present study was to work out an efficient approach of regeneration system directly from leaf discs and genetic transformation of apple cvs. , Golden Delicious', ,Royal Gala' and ,MM111', ,M26' rootstocks for improving their fungal resistance using the g2PS1 gene from Gerbera hybrida.

\section{Materials and methods}

This study has been carried out at the General Commission for Scientific Agricultural Research (GCSAR), Biotechnology Department, Genetic Engineering Division during the period 2010-2013. The cloning of the $g_{2} p s_{1}$ gene was carried out at the section of Plant Biotechnology, Institute of Plant Genetics, Leibniz Hannover University, Hannover, Germany.
Adventitious shoot regeneration: Shoot cultures were obtained from in vitro proliferating shoots of cvs. Golden Delicious, Royal Gala and MM111, M26 apple rootstocks maintained at the Department of Biotechnology which has been subcultured on storage and proliferation media for six years.

The first apical 3-4 youngest unfolded leaves but still in an active state of leaf expansion showing no signs of chlorosis with light green color and strong vein pattern on back of the leaf on the shoot apex were harvested from 3-weeks old proliferating cultures and cut to three parts (upper, middle and lower), but using only the middle part of leaf for regeneration and transformation based on our previous explorations (Ali Bacha et al. 2009). Explants were cultured in $90 \mathrm{~mm}$-diameter Petri dishes with $20 \mathrm{ml}$ of different media as shown in table 1 placing the abaxial face in contact with the medium with five leaf sections were cultured in each plate. All media were adjusted to $\mathrm{pH} 5.7$ prior to autoclaving at $121^{\circ} \mathrm{C}, 1.4 \mathrm{~kg} / \mathrm{cm}^{2}$ for $20 \mathrm{~min}$.

For 'direct' adventitious regeneration, leaves were cultured on different media in darkness for an initial 3 weeks at $25^{\circ} \mathrm{C} \pm 1$ and then transferred to a $16 \mathrm{~h} / 8 \mathrm{~h}$ light/ darkness regime for further 4 weeks to assess morphogenetic responses.

For shoot multiplication of regenerated shoots, the concentrations of NAA, BAP, were investigated previously where it was found that the optimum shoot multiplication media consisted of MS salts, $30 \mathrm{~g} \mathrm{l}^{-1}$ sucrose, $1 \mathrm{mg} \mathrm{l}^{-1} \mathrm{BAP}$, $0.3 \mathrm{mg} \mathrm{l}^{-1}$ IBA, $0.2 \mathrm{mg} \mathrm{l}^{-1} \mathrm{GA} 3$ and $6 \mathrm{~g} \mathrm{l}^{-1}$ Agar (pH 5.7) (Ali Bacha.,et al. 2009).

Table 1. Media used for regeneration of apple using leaf discs as explants

\begin{tabular}{|l|c|}
\hline \multicolumn{1}{|c|}{ Media Composition } & Code \\
\hline MS+2.5 g/l Gelrite + 30 g/l Sucrose (control medium) & MS=R0 \\
\hline $\begin{array}{l}\text { MS+2.0 mg/l TDZ+0.2 mg/l NAA+2.5 g/l } \\
\text { Gelrite + 30 g/l Sucrose }\end{array}$ & $\mathrm{R} 1$ \\
\hline $\begin{array}{l}\text { MS+ } 5.0 \mathrm{mg} / \mathrm{l} \mathrm{BAP+0.2} \mathrm{mg/l} \mathrm{NAA+2.5} \mathrm{g/l} \\
\text { Gelrite + 30 g/l Sucrose }\end{array}$ & $\mathrm{R} 2$ \\
\hline $\begin{array}{l}\text { MS+ 0.5 mg/l TDZ +0.5 mg/l BAP + 0.2 mg/l } \\
\text { NAA+2.5 g/l Gelrite + 30 g/l Sucrose }\end{array}$ & $\mathrm{R} 3$ \\
\hline $\begin{array}{l}\text { N6 macro + MS micro + B5 vitamin + } 5.0 \mathrm{mg} / 1 \\
\text { BAP + 0.2 mg/l NAA+ 2.5 g/l Gelrite + } \\
30 \mathrm{~g} / 1 \text { Sucrose }\end{array}$ & $\mathrm{R} 4$ \\
\hline
\end{tabular}

Optimization of genetic transformation of apple studied: Several experiments of Agrobacteriummediated genetic transformation of apples studied have been done to transfer $g 2 p s 1$ gene harbored on a pGreenII$35 \mathrm{~S}-\mathrm{g} 2 \mathrm{PS} 1$ plasmid vector (Fig. 1) in order to evaluate its efficiency in conferring tolerance to fungal diseases. Young green leaves were used for transformation using several regeneration media. Young light green leaves were treated with the non-traumatic forcep as recommended by Norelli et al. 1996 to induce wounding and co-cultured for three days with Agrobacterium strain EHA105 harbouring pSoup-pGreenII-35S- $g_{2} p s_{1}$ vector for 3 days (Fig. 1). Cultures were incubated in full darkness for an 
initial 3 weeks in the growth room with temperature of $25{ }^{\circ} \mathrm{C} \pm 1{ }^{\circ} \mathrm{C}$. Cultures were then transferred to exposed distributed light for further one week, where after they were transferred to conditions of a $16 / 8 \mathrm{~h}$ light/darkness regime with $50 \mu \mathrm{mol} \mathrm{m} \mathrm{m}^{-2}$ photon flux to assess their morphogenetic responses.

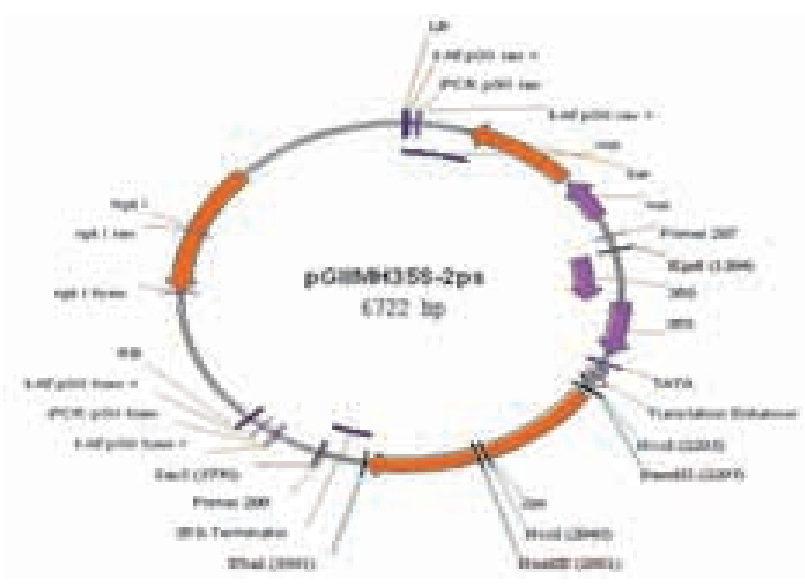

Fig. 1. Map of the pGreen II 35S-g2PS1 harboring the g2ps1 used in the present study

Regenerated shoots were sub-cultured for multiplication on media containing growth regulators in the presence of the selection agent "PPT" at 3.0-5.0 mg $\mathrm{m}^{-1}$ in order to get sufficient material to confirm transformation of the putative shoots obtained. Transformation was confirmed by PCR for the presence of ,bar" and ,g2PSl” genes using specific primers as follows:

For bar gene (447 bp): bar for: 5'-GATTTCGGTGACGGGCAGGA -3' bar rev: 5'-TGCGGCTCGGTACGGAAGTT -3'

For g2ps1 gene (1244 bp):

(g2ps1 for): 5'-CCG ACG GTA CCC CCC CTG CAG GTC GAC GG-3'

(g2ps1 rev.): 5' - GTC GGT CTA GAT CAG TTT CCA TTG GCA ACC GC-3'

The PCR program consisted of an intial incubation at $94{ }^{\circ} \mathrm{C}$ for $3 \mathrm{~min}$. for bar gene and $1 \mathrm{~min}$. for $\mathrm{g} 2 \mathrm{ps} 1 \mathrm{gene}$, followed by 30 cycles for both genes as follows: denatuation at $95{ }^{\circ} \mathrm{C}$ for $1 \mathrm{~min}$., primer annealing at $60^{\circ} \mathrm{C}$ for $1 \mathrm{~min}$. and extension at $72{ }^{\circ} \mathrm{C}$ for $1 \mathrm{~min}$., then final extension at $72{ }^{\circ} \mathrm{C}$ for $10 \mathrm{~min}$. and hold at $4{ }^{\circ} \mathrm{C}$.

Regenerated transgenic shoots were transferred to proliferation media with $1.0 \mathrm{mg} / 1 \mathrm{BAP}, 0.3 \mathrm{mg} / \mathrm{l} \mathrm{IBA}$ and 0.2 $\mathrm{mg} / \mathrm{l} \mathrm{GA3}$. The media used were adjusted to $\mathrm{pH} 5.7$ prior to autoclaving at $121^{\circ} \mathrm{C}, 1.4 \mathrm{~kg} / \mathrm{cm}^{2}$ for $20 \mathrm{~min}$.

Shoots were then transferred to rooting media with half strength MS medium supplemented with $1.0 \mathrm{mg} / \mathrm{l}$ IBA under light intensity of $5.0 \mathrm{~W} \cdot \mathrm{m}^{-2}$ (16 h per day). Rooted transgenic clones were then acclimatized gradually under- containment conditions.

\section{Experimental design}

Scoring for adventitious shoot regeneration and transformation was done after 8 weeks of culture. The following criteria were evaluated: number of explants that produced adventitious shoots and number of shoots produced by each explant showing organogenesis. Each Petri dish was a repetition in a randomized block experimental design. For each treatment, 8 petri dishes (i.e. 40 explants were used). Significance was determined by analysis of variance (ANOVA) and the differences between the means were compared by Duncan's multiple range test using MSTAT-C computer programme (Michigan State University). All the experiments described here were repeated at least twice and results were pooled.

\section{Results}

Explants started regeneration after at least 4 weeks of beginning of the regeneration experiment and continued until the eighth week, where there no regeneration could be seen afterwards. Numerous shoots were produced in each Petri dish between 4-8 weeks.

A regeneration system from leaf discs of apples studied was established on MS based media and supplemented with $1.0 \mathrm{~g} / 1 \mathrm{MES}, 5 \mathrm{mg} / \mathrm{l} \mathrm{BA}$ or $2.0 \mathrm{mg} / \mathrm{l} \mathrm{TDZ}, 0.2 \mathrm{mg} / 1$ NAA, $30 \mathrm{~g} / 1$ Sucrose, $2.5 \mathrm{~g} / 1$ Gerlite. Organogenesis did not occur on media without cytokinins.

The effects of combinations of BAP $x$ NAA and explants on shoot multiplication were statistically significant. $(\mathrm{p}<0.05)$ (Table 1). Most of explants produced shoots and green shoot initials were seen on a range of media containing BAP or TDZ and NAA within eight weeks. The highest percentage of regenerated shoots $(95 \%)$ was achieved on a range of media supplemented with $0.5 \mathrm{mg} / 1$ or $5.0 \mathrm{mg} / \mathrm{l} \mathrm{BAP}+0.2 \mathrm{mg} / \mathrm{l} \mathrm{NAA}$ or 2.0 $\mathrm{mg} / 1 \mathrm{TDZ}+0.2 \mathrm{mg} / \mathrm{l} \mathrm{NAA}$ in leaf explants. Whereas, the highest shoot multiplication capacity $(82 \%)$ was obtained on a medium containing $0.5 \mathrm{mg} / 1 \mathrm{BAP}, 0.5 \mathrm{mg} / 1 \mathrm{TDZ}+0$. $2 \mathrm{mg} / \mathrm{l}$ NAA.

Explants were tested with special attention to the regeneration rate. A high regeneration frequency $(92 \%$, $95 \%$ and $90 \%, 94 \%)$ with good regeneration ability (4.0, 5.6, 4.1 and 4.5 new shoots/explants could be obtained in apples studied respectively on MS basal medium containing $2.0 \mathrm{mg} / 1 \mathrm{TDZ}$ and $0.2 \mathrm{mg} / \mathrm{l} \mathrm{NAA}$ and $3 \%$ sucrose. Middle leaf segments from 21-days old leaves were used and showed higher regenerative responses (table 3 ). Reducing TDZ concentration to $0.5 \mathrm{mg} / \mathrm{l}$, but with adding $0.5 \mathrm{mg} / \mathrm{l}$ BAP could result also in high regeneration frequency (82\%, 90\% and 79\%, 85\% respectively) (Tables $2 \& 3$ ). Adventurous shoots preferentially located along the cut basal edge of the explants were clearly visible after four to five weeks of culture. 
Table 2. Mean shoot number regenerated in vitro (organogenesis ability) per explants in response to the media tested for the apple cvs. and rootstocks

\begin{tabular}{|c|c|c|c|c|}
\hline & \multicolumn{2}{|c|}{ Apple cvs. } & \multicolumn{2}{|c|}{ Apple Rootstocks } \\
\hline Media & $\begin{array}{c}\text { Golden } \\
\text { Delicious }\end{array}$ & Royal Gala & MM111 & M26 \\
\hline R01 & $\begin{array}{l}4.025 \mathrm{a} \\
\pm 0.141\end{array}$ & $\begin{array}{l}5.615 \mathrm{a} \\
\pm 0.121\end{array}$ & $\begin{array}{l}4.100 \mathrm{a} \\
\pm 0.171\end{array}$ & $\begin{array}{l}4.500 \mathrm{a} \\
\pm 0.160\end{array}$ \\
\hline R02 & $\begin{array}{c}2.225 \mathrm{c} \pm \\
0.067\end{array}$ & $\begin{array}{c}2.505 \mathrm{c} \pm \\
0.67\end{array}$ & $\begin{array}{c}2.512 \mathrm{~d} \pm \\
0.80\end{array}$ & $\begin{array}{c}2.100 \mathrm{c} \pm \\
0.80\end{array}$ \\
\hline R03 & $\begin{array}{c}2.525 \mathrm{~b} \pm \\
0.080\end{array}$ & $\begin{array}{c}4.212 \mathrm{~b} \pm \\
0.080\end{array}$ & $\begin{array}{c}2.800 \mathrm{~b} \pm \\
0.103 \\
\end{array}$ & $\begin{array}{c}3.100 \mathrm{~b} \pm \\
0.103\end{array}$ \\
\hline R04 & $\begin{array}{c}1.575 \mathrm{~d} \pm \\
0.080 \\
\end{array}$ & $2.00 \mathrm{~b} \pm 0.80$ & $1.65 \mathrm{c} \pm 0.80$ & $1.500 \mathrm{c} \pm 0.60$ \\
\hline RO & 0.00 & 0.00 & 0.00 & 0.00 \\
\hline LSD 0.05 & 0.290 & 0.310 & 0.293 & 0.301 \\
\hline
\end{tabular}

Note: *Values within each column followed by different letters are significantly different at the 0.05 probability level $(\mathrm{a}<0.05 \%)$ using Duncan's multiple range test.

Table 3. Organogenesis/ Regeneration \% in vitro in Apple cvs. and rootstocks on different media using middle part of the leaves

\begin{tabular}{|l|c|c|c|c|}
\hline \multirow{2}{*}{ Media } & \multicolumn{2}{|c|}{ Apple CVs. } & \multicolumn{2}{c|}{ Apple Rootstocks } \\
\cline { 2 - 5 } & $\begin{array}{c}\text { Golden } \\
\text { Delicious }\end{array}$ & Royal Gala & MM111 & M26 \\
\hline R01 & 92 & 95 & 90 & 94 \\
\hline R02 & 20 & 20 & 18 & 20 \\
\hline R03 & 82 & 90 & 79 & 85 \\
\hline R04 & 36 & 30 & 10 & 15 \\
\hline RO & 0 & 0 & 0 & 0 \\
\hline
\end{tabular}

Overall organogenesis was satisfactory in all treatments both in terms of regeneration rate and of adventitious shoot production using mid-leaf explants (Figure 2). Further, no abnormality, necrosis or chlorosis was observed during the culture.

Putative transgenic shoots could be obtained on MS media with B5 Vitamins, $5.0 \mathrm{mg} \mathrm{l}^{-1} \mathrm{BAP}$, or $2.0 \mathrm{mg} \mathrm{l}^{-1} \mathrm{TDZ}$ with 0.2 $\mathrm{mg}^{-1}$ NAA in the presence of the selection agent "PPT" at 3.0-5.0 $\mathrm{mg} \mathrm{l}^{-1}$. Appearance of putative transgenic shoot initials on leaf explants could be seen after 4-8 weeks of culture. However, excessive wounding could be detrimental initially by slowing down regeneration, due to oxidation of the tissues.

Transformed explants regenerated on media containing the selection agent. They were divided and subcultured further on media with PPT at concentrations of 3-5 mg/l and could survive in the presence of the selection agent „PPT”,while the non-transformed explants were died (brown tissues) (Figure 3).

These survivd putative transformants were further subcultured and proliferated further in vitro in the presence of the selection agent ,PPT' and rooted also on media containing PPT (Figure 4). As for the performance of the adventitious shoots, they were multiplied and rooted easily according to the protocols developed by Altinawi et al. 2008 for the cv. Golden Delicious and Alrihani et al. 2008 for MM111 rootstock.

\section{Molecular Confirmation of Transformation by PCR}

Confirmation of putative transgenic regenerants was carried out by PCR. Specific primers for detection of the selection bar gene and also for the gene of interest ,,g2PS1'

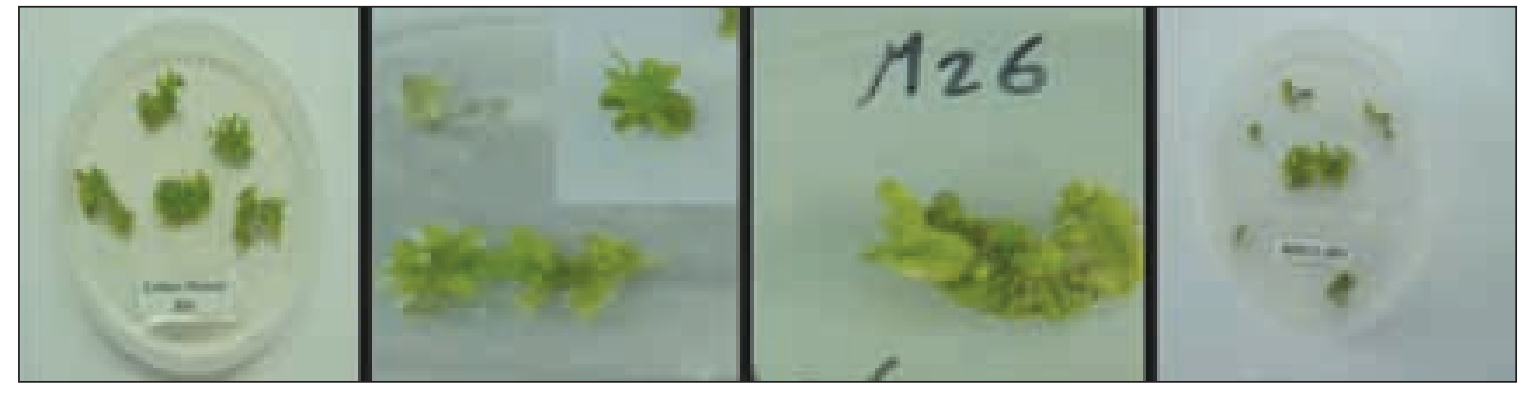

Figure 2

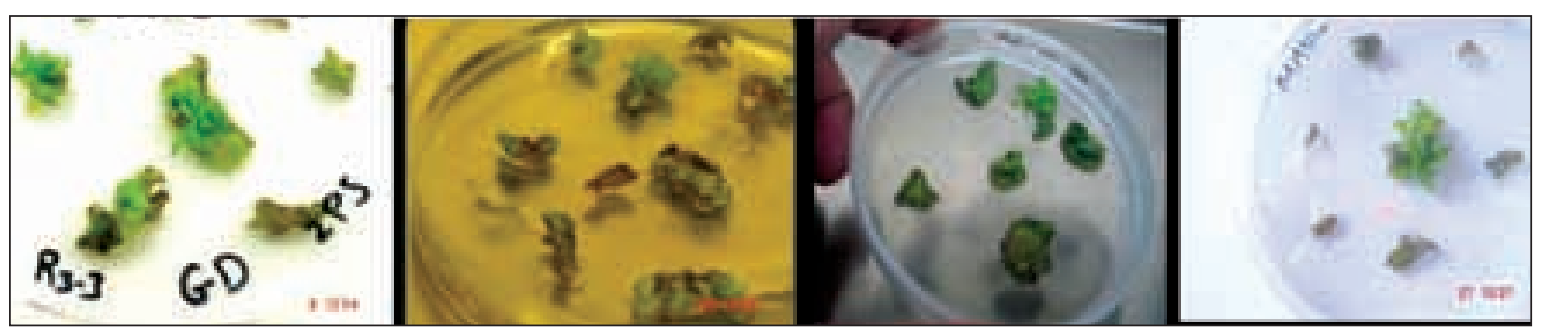

Figure 3 


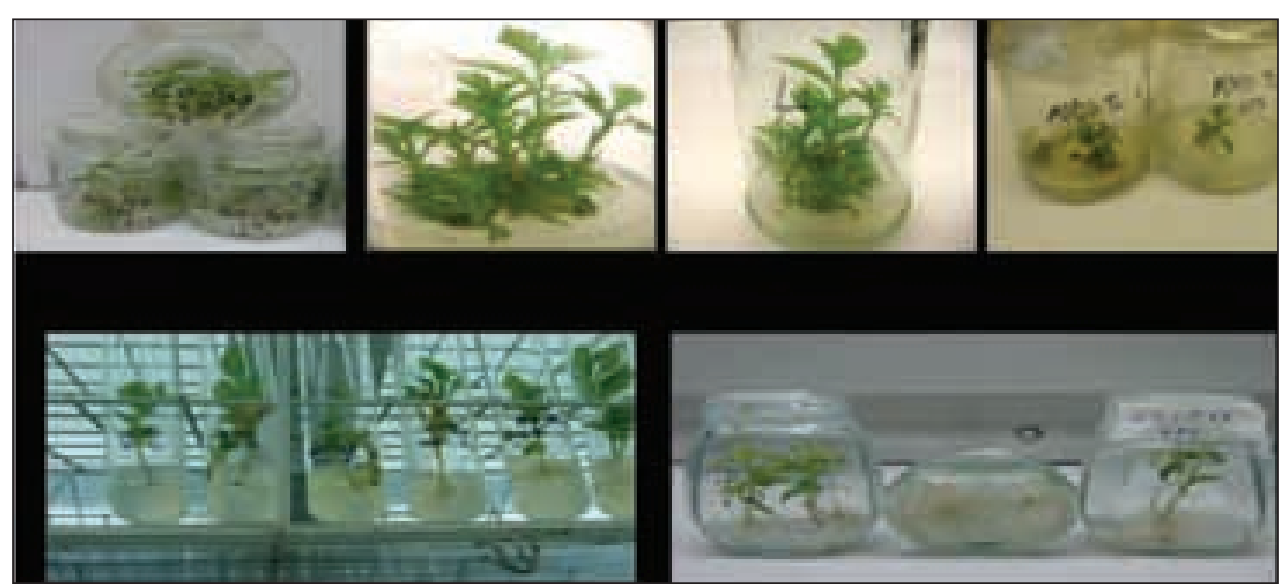

Figure 4

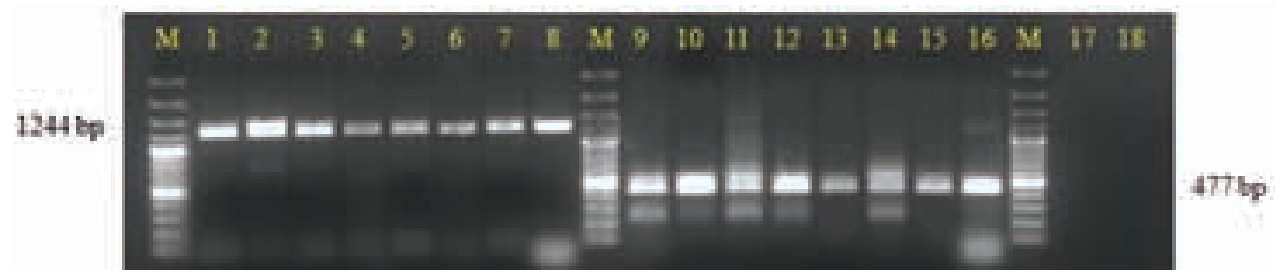

Figure 5. Molecular Confirmation of Transformation by PCR for the gene of interest g2ps1 and the selection agent bar gene.

Lanes: 1,2 GD; 3,4: M26; 5,6: RG, 7: MM111, 8: positive control.

Lanes: 9,10: GD; 11,12: M26; 13,14: RG; 15: MM111, 16: positive control; 17: water,18: negative control (DNA isolated from non-transformed apple)

M: 100 bp marker

showed the transfer of the gene according to the expected band size of $447 \mathrm{bp}$ for the bar gene and $1244 \mathrm{bp}$ for the gene-of-interest „g2PS1” gene, while no band was shown in the negative control -not transformed apple-, nor in the water containing lane as negative control (well, containing no DNA)

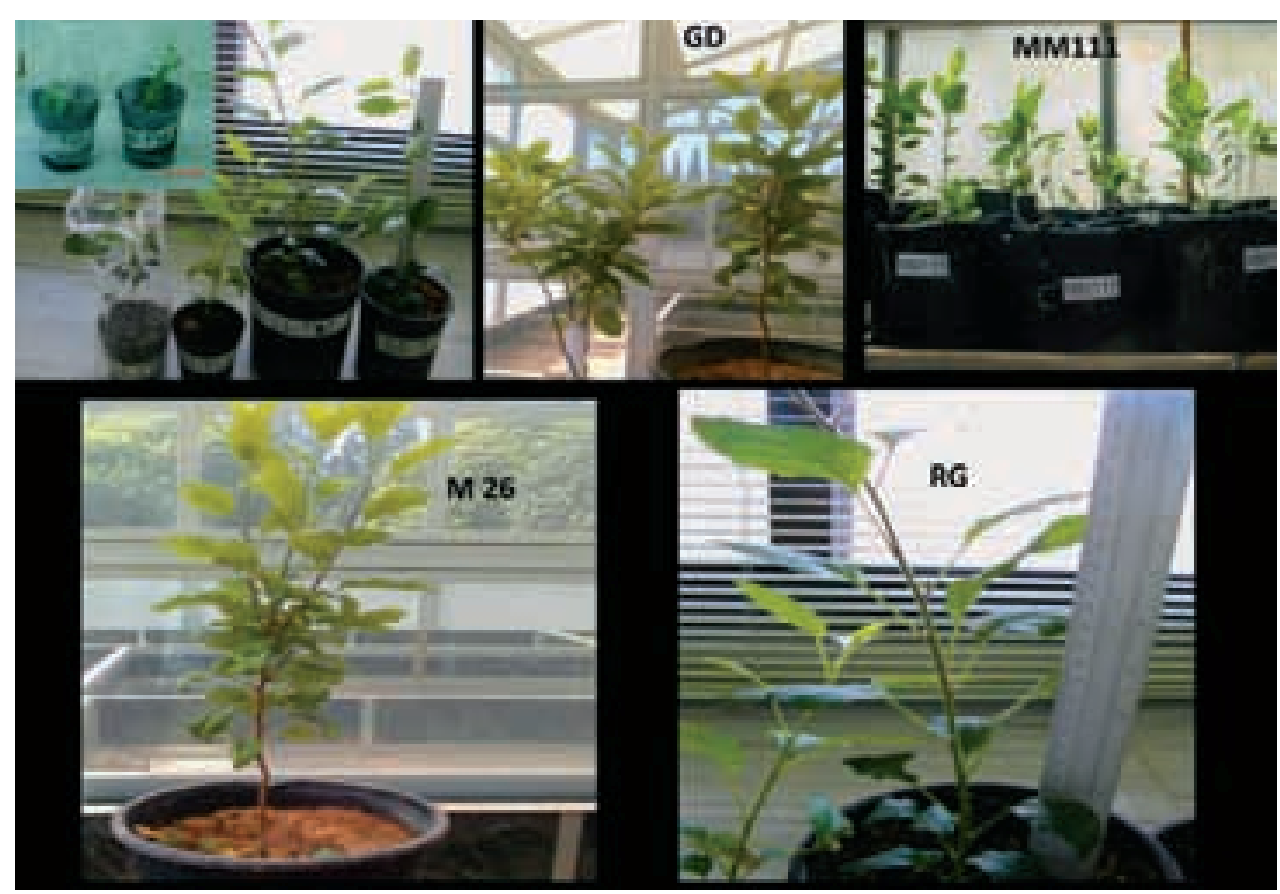

Figure 6
(Figure 5). Six, seven, one and six transgenic clones of the apples studied respectively have been obtained and confirmed by selection on the media containing the selection agent „PPT" and by PCR analysis using the suitable primers in all clones obtained for the presence of the selection" bar gene (447 bp) and the geneof- interest " $g 2 P S 1$ " (1244 bp), with transformation efficiency of $0.4 \%, 0.6 \%, 0.1 \%$ and $0.3 \%$ respectively.

\section{In vitro rooting of transgenics}

Roots were formed easily in the presence of the selection agent PPT within 2-4 weeks with about $85 \%$ efficiency in apples studied (fig. 4)

\section{Acclimatization of rooted transgenics}

Rooted transgenic plantlets were successfully acclimatized to ambient conditions with about $70 \%$ efficiency and kept in the greenhouse under containment conditions according to the biosafety by-law in Syria to evaluate their performance for fungal resistance (Figure 6).

\section{Discussion}

Cytokinins such as TDZ and BAP have considerrable effects in inducing regeneration in most woody plants. For shoot regeneration from leaf discs, a range of BAP and TDZ concentrations was examined. Although induction of shoots was observed in most media tested in the present study, however, there was statistically significant difference between the TDZ and BA. However, other studies show that TDZ is more effective than BAP (Korban et al.,1992; DeBond et al., 1996; Sarwar and Sirvin,1997; Hammatt and Grant,1998). Whilst ,Greensleeves' apple 
responded in line with published data, ,Bramley' produced significantly fewer shoots. ,Bramley' shoots were obtained from $5.0 \mathrm{mg} \mathrm{l}^{-1} \mathrm{BAP}$ and $1 \mathrm{mg} \mathrm{l}^{-1} \mathrm{NAA}$. TDZ did not increase regeneration significantly. TDZ was also used to induce adventitious shoot regeneration in many other plants including Phaseolus vulgaris L (Malik and Saxena 1992) henbane Hyoscyamus niger L., (Uranbey 2005), mulberry (Thomas 2003), Lentil (Lens culinaris Medik.) (Khawar et al. 2004); peanut (Arachis hypogaea) (Kanyand et al. 1994). McAdam-O Connell et al. (2004) developed a leaf disk regeneration system for ,Bramley's' seedling apple (Malus $\times$ domestica Borkh.) and obtained shoots using MS media with $5.0 \mathrm{mg} \mathrm{l}^{-1} \mathrm{BAP}$ and $1 \mathrm{mg} \mathrm{l}^{-1} \mathrm{NAA}$, whereas TDZ did not increase regeneration significantly. Our results, however, are in contrary to such findings where TDZ proved to be more efficient in inducing regeneration in apples studied than BAP. A detailed review on apple micropropagation also showed using mostly both BAP and TDZ for inducing regeneration in many apples varities and rootstock with different responses (Dobranszki and Teixeira da Silva 2010). In the present study, the percentage of explants producing shoots and the number of shoots per explant were influenced by the type and concentrations of TDZ and BAP tested (p.0.05). The percentage of regenerated shoots fluctuated between 6-95\% while the highest number of shoots per explant ranged between 4 and 5.6 which occurred with 2.0 $\mathrm{mg} / \mathrm{l} \mathrm{TDZ}$ and $0.20 \mathrm{mg} / \mathrm{l} \mathrm{NAA}$. Considering both percentage of explants producing shoots and the number of shoots per explant, the best shoot multiplication was achieved on media supplemented with $2.0 \mathrm{mg} / \mathrm{l} \mathrm{TDZ}$ and $0.20 \mathrm{mg} / \mathrm{l} \mathrm{NAA}$. Drastic reductions in shoot regeneration were also observed when decreasing of concentrations of TDZ or replacing it with BAP. This effect of TDZ is in conformity with many studies where shoot organogenesis of some crops in tissue culture have been achieved using Thidiazuron (TDZ), a substituted phenylurea compound with cytokinin activity (Malik and Saxena, 1992; Kanyand et al., 1994; Kim et al., 1997; Jain and Rashid, 2001, Hosseini and Rashid, 2003; Thomas, 2003; Uranbey, 2005). Gill and Saxena (1992) suggested a crucial role of TDZ in the interaction with endogenous hormones in reprogramming the mode of morphogenesis from organogenesis to somatic embryogenesis possibly by releasing, synthesizing, protecting or even inhibiting auxins in situ in combination with other sub-cellular metabolic changes, particularly in key regulatory enzyme and related proteins.

Similarly, auxins such as IAA, NAA, IBA in combination with cytokinins have also great effect on regeneration (Yancheva et al., 2003). Frequency of shoot organogenesis may be increased with combinations of TDZ and NAA. Combinations of TDZ-NAA in the media revealed an efficient pathway for shoot proliferation in leaves of apple. In the present study, it was observed that the use of NAA with TDZ produced satisfactory responses that might be the best treatment to eliminate the secretion of phenolic substances and this effect might be also due to the oxidation of phenols by auxin oxidase.
On the other hand, regeneration of adventitious shoots is still difficult in many species and cultivars. The optimum conditions for shoot regeneration vary according to the genotype thus methods should be fitted for each genotype. Regeneration efficiencies for apples (up to 50\% regeneration rate for several genotypes) reported could be further improved with new methods. Moreover, there are some cultivars without published regeneration methods (Tabori 2011). There are two possible reasons why regeneration ability in plant tissue culture (PTC) differs from study to study. In life, not all beings are born equal. In PTC, too, not all explants have the same regeneration capacity. A plethora of factors influence the organogenic outcome of an explant in PTC, but differences in production, yield and organogenic output are all measured by one factor, and one factor alone: the size of the explant. In this ground-breaking paper, we put forward a radical notion that would attempt to allow for the direct comparison of organogenic potential of PTCs of the same cultivar or species conducted in different studies or laboratories. The prototype concept, the growth correction factor or GCF, has been tested on a model species, apple (Malus sp.) (Teixeira da Silva and Dobránszki 2011).

Five-minute daily exposures of leaf explants to red light $(651 \mathrm{~nm})$ suppressed adventitious shoot formation by $80 \%$; five-minute exposure to far-red light $(729 \mathrm{~nm})$ immediately following the red light counteracted the red suppression. (Liu et al. 1983). In our experiments, however, we incubated explants for the first three weeks in complete darkness and did not expose explants to any source of light. Dufour (1990) obtained improved yield in in vitro adventitious regeneration in apple cultivars ,Granny' Smith', ,Mark', ,Novole', ,Lancep' and ,Cepiland with significant increase in the number of regenerated shoots from , Gala' and , Golden Delicious'. He regenerated Plants from callus or directly from leaves from micropropagated plants. He got $100 \%$ regenerating leaves with an average of 14.2 regenerated shoots per leaf in ,Gala', In vitro adventitious regeneration in apple cultivars ,Granny' Smith', ,Mark', ,Novole', ,Lancep' and ,Cepiland' was reported with a significant increase in the number of regenerated shoots from ,Gala' and ,Golden Delicious'.

Our preliminary experiments of transformation showed that treating the leaves with the non-traumatic forcep resulted in a higher and faster organogenic and transformation responses, due to severe wounding and Agrobacteriummediated gene transfer in accord with what was observed in the previous experiments by Norelli et al. 1996. This also confirms earlier observations (Ferradini et al. 1996, Sicurani et al. 2001) showing that leaves are good explants for adventitious shoot formation. However, it should be pointed out that selection, excision, wounding and arrangement on the medium was time-consuming and labor- intensive. However, it worth it since wounding of tissues boosted the regeneration efficiency of transformants. Hemerly et al. (1993) explained that wounding of plant tissues triggers the expression of genes in cell division and differentiation. The positive effect of wounding on regeneration was demonstrated for M26 
apple rootstock by Sicurani et al. 2001 and also in other species (Piccioni and Valecchi, 1996).

While, on the other hand, genetic engineering has been used very successfully mostly with other crops than apple, which included mainly: corn, cotton, soybean, canola, tomato and papaya to produce disease, insect, and herbicide-resistant varieties that were grown on over 170 million hectares of GM crops worldwide in 2012. Twenty-eight countries planted GM crops in 2012, but most were grown in just five countries: The United States, Brazil, Argentina, Canada and India (James 2013). However, such technology should solve many of our apple cultivation diseases. It will allow us to improve the shortcomings of our present varieties and rootstocks, without altering their desirable features, especially familiarity to nurseries and growers, and recognition in the market by brokers, supermarkets, and consumer (Aldwinckle et al. 2000). Polanco et al. (2010) summarize in their reiew the advances of genetic engineering applied to the development of resistant apple cultivars to fungus disease, with particular attention in the generation of apples resistant to apple scab Venturia inaequalis. The present work contribute to the researcher efforts to produce fungal resistant apple.

Finally, it might be relevant to mention that no environmental risk studies specific to transformed apple have been published. Probably researchers are still concerned with producing acceptable GM apple cultivars with commercial interest and having environmental benefits, such as reduction of pesticides use (James et al., 2003). Under these circumstances, the commercialization of transgenic apple carrying a DNA from different species or genera, in the near future is certain (Polanco et al. 2010).

\section{Conclusions}

- An efficient approach of regeneration from leaf discs and genetic transformation for apple cvs. 'Golden Delicious', 'Royal Gala' and 'MM111', 'M26' rootstocks were worked out for improving their fungal resistance using genetic engineering techniques.

- From the present study, it was established that cytokinins TDZ and BAP played an important role in induction of direct shoot organogenesis in in vitro leaf discs of apples studies and the response could be further improved by combination of TDZ with the auxin NAA in the regeneration medium. Though TDZ proved to be superior to BAP in inducing regention, however, BAP has economic advangave over TDZ and can replace it. Further, efficiency of direct shoot organogenesis and transformation in the presence of the selection agent PPT could be substantially improved by wounding leaves with non-traumatic forcep treatment before culturing them on cocultivation medium.

- Transgenic apples harbouring g2ps1 gene from Gerbera hybrida that confer fungal resistance were obtained. Six, seven, one and six transgenic clones of the GD, RG, MM111 and M26 apples studied respectively have been obtained and confirmed by selection on the media containing the selection agent "PPT" at high concentration of $5.0 \mathrm{mg} / \mathrm{l}$ and by PCR analysis using the suitable primers in all clones obtained for the presence of the selection" bar gene and the gene-of-interest " $g 2 P S l$ ", with satisfactory transformation efficiency. These transgenic clones were multiplied further and rooted in vitro also in the presence of the selection agent 'PPT'. Rooted transgenic plantlets were successfully acclimatized and are being kept undercontainment conditions to evaluate their performance for fungal resistance.

\section{Acknowledgements}

- g2ps1 gene cloning was done at Leibniz Hannover University with a fellowship to the corresponding author from Alexander von Humboldt Foundation (AvH), Bonn, Germany. AvH and the host university are accordingly deeply acknowledged.

- GCSAR acknowledge equipment donations provided by Alexander von Humbodlt Foundation, Germany which were used in this research.

\section{References}

Abdul Kader, A.; Norelli, J.L.; Aldwinckle, H.S.; Bauer, W.B.; Beer S.V. (1999): Evaluation of the $h r p N$ gene for increasing resistance to fire blight in transgenic apple. Acta Horticulturae. 489: 247-250.

Aldwinckle H., Norelli J., Brown S.,Robinson T., BorejszaWysocka E., Gustafson H., Reynoird J.-P. and Reddy M.V. B. (2000): Genetic Engineering of Apple for Resistance to Fire Blight. New York Fruit Quarterly. 8 (1): 17-19.

Aldwinckle HS, Borejsza-Wysocka EE, Malnoy M, Brown SK, Norelli JL, Beer SV, Meng X, He SY, Jin QL (2003): Development of fire blight resistant apple cultivars by genetic engineering. Acta Horticulturae. 622: 105-111.

Aldwinckle H and Malnoy M. (2009): Plant Regeneration and Transformation in the Rosaceae. Transgenic Plant Journal 3 (Special Issue 1), 1-39.

Ali Bacha, N.; Abdul-Kader, A.; Darkazanly, K. (2009): Direct organogenesis and plantlet multiplication from leaf explants of in vitro-grown shoots of apple (Malus domestica Borkh) cv. 'Golden Delicious' and 'MM111' rootstock. Fruit, Vegetable and Cereal Science and Biotechnology. 3 (1): 28-43.

Al-Rihani ,K. ; Khalhout, A.; Dayoub, A.; Abdul-Kader, A. (2008): A study on in vitro propagation of the apple rootstock 'MM111'. Jordan Journal of Agricultural Sciences. 4: 191-205.

Al-Tinawi, E.; Ali Bacha, N.; Al-Rihani, K.; Abdul Kader, A.; (2009): In vitro micro propagation of apple cv. 'Golden Delicious' using tissue culture technique. Al-Bassel Journal for Agricultural Engineering Sciences. Ministry of Higher Education, Syria, 26.

Atkinson RG, Schroder R, Hallet IC, Cohen D, MacRae EA (2002): Overexpression of polygalacturonase in transgenic apple trees leads to a range of novel phenotypes involved in cell adhesion. Plant Physiology. 129: 122-133. 
Artlip T, Wisniewski M, Norelli JL, Cui M, Fuchigami L (2007): Using biotechnology to improve resistance to environmental stress in fruit crops: The importance of understanding physiology. Acta Horticulturae. 738: 145-156.

Borejsza-Wysocka, E.E.; Norelli, J.L.; Aldwinckle, H.S. and Ko, K. (1999): Transformation of authentic M.26 apple rootstock for enhanced resistance to fire blight. Acta Hort. (ISHS) 489: 259-266.

Borejsza-Wysocka, E.E.; Malony, M.; Meng, X.; Bonasera, J.M.; Nissinen, R.M.; Kim, J.F.; Beer, S.V.; Aldwinckle, H.S. (2004): Silencing of Apple proteins that interact with DSPE, a pathogenicity effector from Erwinia amylovora as a strategy to increase resistance to fir blight. Acta Hort. (ISHS) 663: 469-474.

De Bondet, A.; Eggermont, K.; Druart, P.; De Vil, M.; Godris, I.; Vanderleyden, J.; Broekaert, W.F. (1994): Agrobacteriummediated transformation of apple (Malus x domesestica Borkh.): an assessment of factors affecting gene transfer efficiency during early transformation steps. Plant Cell Reports. 13: 587-593.

De Bondt, A.; Eggermont, K.; Penninckx, I.; Goderis, I.; Broekaert, W.F. (1996): Agrobacterium-mediated transformation of apple (Malus domestica Borkh): an assessment of factors affecting regeneration of transgenic plants. Plant Cell Reports. 15: 549-554

Dobránszki J. and Teixeira da Silva JA (2010): Micropropagation of apple - A review. Biotechnology Advances. 28: 462-488.

Dufour M. (1990): Improving yield of adventitious shoots in apple. Acta Horticulturae (ISHS). 280: 51-60.

Espley RV, Hellens RP, Putterill J, Stevenson DE, Kutty-Amma S, Allan AC (2007): Red colouration in apple fruit is due to the activity of the MYB transcription factor, MdMYB10. The Plant Journal 49: 414-427-

FAO (2012): http://faostat.fao.org/site/567/DesktopDefault.aspx? PageID=567\#ancor

Faize, M.; Malnoy, M.; Dupuis, F.; Chevalier, M.; Parisi, L. and Chevreau, E. (2003): Chitinases of Trichoderma atroviride induce scab resistance and some metabolic changes in two cultivars of apple. Phytopathology. 93: 1496-1504.

Faize, M.; Sourice, S.; Dupuis, F.; Parisi, L.; Gautier, M.F. and Chevreau, E. (2004): Expression of wheat puroindoline-b reduces scab susceptibility in transgenic apple (Malus domestica Borkh.).Plant Sci. 167: 347-354.

Ferradini, N.; Famiani, F.; Proietti, P.; Stanica, F. (1996): Influence of growth regulators and light on in vitro shoot regeneration in 'M.26' apple rootstock. Journal of Horticultural Science. 71: 859-865.

Gill, R. And Saxena, PK. (1992): Direct somatic embryogenesis and regeneration of plant from seedling explant of peanut (Arachis hypogae L.: Promotive role of thidiazouron. Can. J. Bot. 70: 11861192.

Hanke V, Hiller I, Klotzsche G, Richter K, Norelli JL, Aldwinckle HS (2000): Transformation in apple for increased disease resistance. Acta Horticulturae. (ISHS) 538: 611-616.

Hrazdina G, Kiss E, Galli Z, Rosenfield C, Norelli JL, Aldwinckle HS (2003): Down regulation of ethylene production in Royal Gala apples. Acta Horticulturae. (ISHS) 628: 239-251.

Helariutta Y, Elomaa P, Kotilainen M, Griesbach RJ, Schroder J, Teeri TH. (1995): Chalcone synthase-like genes active during corolla development are differentially expressed and encode enzymes with different catalytic properties in Gerbera hybrida (Asteraceae). Plant Mol Biol. 28 (1): 47-60.
Hemmat, N. and Grant, N.J. (1998): Shoot regeneration from leaves of Prunuse serotina Ehrh. (black cherry) and P. avium L. (wild cherry). Plant Cell Reports. 17: 526-530.

Hemerly, A.S.; Ferreira, P.de.; Almeida Engler, J.; Van Montagu, M.; Engler, G.;Inzé, D. (1993): Cdc2a expression in Arabidopsis is linked with competence for cell division. Plant Cell. 5 (12): 1711-23.

Holefors, A.; Xue, Z-T. and Welander, M.(1998):Transformation of the apple rootstock M26 with the rolA gene and its influence on growth. Plant Sci. 136: 69-78.

Holefors, A.; Xue, Z.T.; Zhu, L.H.; Welander, M. (2000): The Arabidopsis phytocrome B gen influences growth of the apple rootstock M26. Plant Cell Reportes. 11:1049-1056.

Hosseini-Nasr, M. and Rashid, A. (2003): Thidiazuron-Induced High-Frequency Shoot Regeneration from Root Region of Robina pseudoacacia L. seedlings. Biologia Plantarum. 47 (4): 593-596.

Hyung, N.I.; Lee. C.H. and Kim. S.B. (1995): Foreign gene transfer using electroporation and transient expression in apple (Malus domestica Borkh). Acta Hort. (ISHS) 392: 179-185.

Jain, R. and Rashid, A. (2001): Stimulation of shoot regeneration on Linum hypocotyl segments by thidiazuron and its response to light and calcium. Biologia Plantarium. 44 (4): 460-481.

James C. (2013): Nature's GM Crops: A story in numbers. Nature 497 (7447): 22-23.

James, D., A. Passey, S. Baker, F. Wilson, J. Stow, R. Colgan, et al. (2003): Genetic modification to improve fruit quality: benefits for the grower, the consumer and the environment. Acta Hort. (ISHS) 622: 97-104.

Kanyand, M.; Dessaim, AP.; Prakash, CS. (1994): Thidiazuron promotes high frequency regeneration of peanut (Arachis hypogaea) plants in vitro. Plant Cell Reports. 14: 1-5.

Khawar, M.K.; Sancak, C.; Uranbey, S.; Ozcan, S. (2004): Effect of thidiazuron on shoot regeneration from different explants of Lentil (Lens culinaris Medik.) via organogenesis. Turk. J. Bot. 28: 421-426.

Kim, Mk.; Sommer, HE.; Bongarten, BC.; Merkle, SA. (1997): High frequency induction of adventitious shoots from hypocotyls segments of Liquidambar styraciflua L. by thidiazouron. Plant Cell Reports 16: 536-540.

Ko K, Norelli, JL; Reynoird, JP.; Boresjza-Wysocka, E.; Brown, SK. and Aldwinckle, HS. (2000): Effect of untranslated leader sequence of AMV RNA 4 and signal peptide of pathogenesisrelated protein $1 \mathrm{~b}$ on attacin gene expression and resistance to fire blight in transgenic apple. Biotechnol. Lett. 22: 373-381.

Korban, S.S.; O,Conner, P.A. and Edobeidy, A. (1992): Effect of thidiazouron, naphthalenacetic acid, dark incubation and genotype on shoot organogenesis from Malus leaves. J. Hortic. Sci. 67: 341349.

Liu, J. R.; K. C. Sink and Dennis. F. G. (1983): Plant regeneration from apple seedling explants and callus cultures. Plant Cell, Tissue and Organ Culture, 398: 293-304.

Liu Q, Salih S, Hammerschlag F (1998): Etiolation of 'Royal Gala' apple (Malus X domestica Borkh.) shoots promotes high frequency shoot organogenesis and enhanced E-glucuronidase expression from stem internodes. Plant Cell Reports. 18: 32-36.

Liu, Q.; Ingersollj, OL; Salih S.; Meng R.; Hammerschlag, F. (2001): Response of transgenic Royal Gala apple (Malus $\times$ domestica Brokh.) shoots carrying a modified ceceropin MB39 gene to Erwinia amylovora. Plant Cell Reports. 20: 306-312. 
Malik, K.A. and Saxena, P.K. (1992): Regeneration in Phaseolus vulgaris L.: High frequency induction of direct shoot formation in intact seedlings by N6-benzylaminopurine and thidiazuron. Planta 186: 384-389.

Malnoy M, Reynoird JP, Borejsza-Wysocka E, Aldwinckle HS (2006): Activation of the pathogen-inducible Gst1 promoter of potato after elicitation by Venturia inaequalis and Erwinia amylovora in transgenic apple (Malus. domestica). Transgenic Research 15: 83-93.

Malnoy, M.; Jin, E.Q.; Borejsza-Wysocka E.; He S.Y. and Aldwinckle H.S. . (2007a): Over-expression of the Apple MpNPR1 Gene Confers Increased Disease Resistance in Malus $\times$ domestica. Molecular Plant-Microbe Interactions. 20 (12): 1568-1580.

Malnoy M, Borejsza-Wysocka E, Abbott P, Lewis S, Norelli J, Flaishman M, Gidoni D Aldwinckle HS (2007b) Genetic transformation of apple without use of a selectable marker. Acta Horticulturae. (ISHS) 738: 319-322.

Markwick NP, Docherty LC, Phung MM, Lester MT, Murray C, Yao JL, Mitra DS, Cohen D, Beuning LL, Kutty-Amma S, Christeller JT (2003): Transgenic tobacco and apple plants expressing biotin-binding proteins are resistant to two cosmopolitan insect pests, potato tuber moth and lightbrown apple moth, respectively. Transgenic Research. 12: 671-681.

Maxemova, S.N.; Dandekar, A.M. and Guiltinan, M. (1998): Investigation of Agrobacterium-mediated transformation of apple using green fluorescent protein: high transient expression and low stable transformation suggest that factors other than T- DNA transfer are rate limiting. Plant Molecular Biology, 37 (3): 549-559.

McAdam-O'Connell, D.; MacAntsaoir, S.; Copeland, R.(2004): Development of a leaf disc regeneration system for ,Bramley's' seedling apple (Malus $\times$ domestica Borkh.). Acta Horticulturae. (ISHS) 663: 483-486.

Murashige, T.; Skoog, F. (1962): A revised medium for rapid growth and bioassays with tobacco tissue cultures. Physiologia Plantarum. 15: 473-497.

Norelli, J.L.; H.S. Aldwinckle, L.; Destéfano-Béltran, J.M.; Jaynes. (1994): Transgenic „Malling 26” apple expressing the attacin E gene has increased resistance to Erwinia amylovora. Euphytica. 77 (1-2): 123-128.

Norelli, J.L.; Mills, J.A.; and Aldwiinckle, H.S. (1996): Leaf wounding increases efficiency of Agrobacterium-mediated transformation of apple. HortScience 31 (6): 1026-1027.

Norelli, J.L.; Borejsza-Wysocka, E.; Momol, T.M.;Aldwinckle, H.S.; Abdul Kader A.M; Bauer W.B; Beer S.V. (1999): Genetic transformation for fire blight resistance in apple. Acta Horticulturae (ISHS) 489: 295-296.

Norelli JL, Basset CL, Artlip TS, Aldwinckle HS, Malnoy M, Boresjza-Wysocka E, Gidoni D, Flaishman MA (2007) Inducible DNA promoters for use in apple. Acta Horticulturae. (ISHS) 738: 329-334.

Piccioni E \& Valecchi G (1996): Effects of wounding and of rooting in the regenerative ability of micropropagated alfalfa tissues. Agr. Med. 126: 311-315.

Polanco V., Paredes M., Becerra V. and Pérez E. (2010): Advances in apple transformation technology to confer resistance to fungal diseases in apple crops: a chilean perspective. Chilean Journal of Agricultural Research. 70 (2): 297-308.
Puite, K.J.; Schaart, J. G. (1996): Genetic modification of the commercial apple cultivars Gala, Golden Delicious and Elstar via an Agrobacterium-mediated transformation method. Plant Science, 119: 125-133.

Puite, K. and Schaart, J. (1998): Agrobacterium-mediated transformation of the apple cultivars 'Gala', 'Golden Delicious' and 'Elstar', and the strawberry cultivars 'Gariguette', 'Golka' and 'Elsanta'. Acta Hort. (ISHS) 484: 547-556.

Schaart JG, Puite KJ, Kolova L, Pogrebnyak N (1995): Some methodological aspects of apple transformation by Agrobacterium. Euphytica 85: 131-134.

Sarwar M.; Skirvin, R.M. (1997): Effect of thidiazuron and 6-benzylaminopurine on adventitious shoot regeneration from leaves of three strains of 'McIntosh' apple (Malus domestica Borkh.) in vitro. Scientia Horticulturae. 68: 95-100.

Sicurani, M., E. Piccioni and A. Standardi (2001): Micropropagation and preparation of synthetic seed in $\mathrm{m} .26$ apple rootstock i: Attempts towards saving labor in the production of adventitious shoot tips suitable for encapsulation. Cultures. 66: 207-216.

Tábori K. M. (2011): The role of cytokinins in in vitro shoot regeneration in apple. Ph.D thesis. Szent István University. Gödöllő, Hungary

Teixeira da Silva J.A. and Dobránszki J. (2011): The Plant Growth Correction Factor. I. The Hypothetical and Philosophical Basis. International Journal of Plant Developmental Biology 5 (1): 73-74.

Theiler-Hedtrich, C.and Theiler-Hedtrich, R. (1990): Influence of TDZ and BA on adventitious shoot regeneration from apple leaves. Acta Horticulturae (ISHS), 280: 195-200.

Thomas, T.D. (2003): Thiadiazuron induced multiple shoot induction and plant regeneration from cotyledonary explants of mulberry. Biol. Plant. 46: 529-533.

Uranbey, S. (2005): Thidiazuron induced adventitious shoot regeneration in henbane (Hyoscyamus niger L). Biol. Plant. 49 (3): 427-430.

Welander M, Pawlicki N, Holefors A, Wilson F (1998): Genetic transformtion of apple rootstock M26 with rolB gene and its influence on rooting. Journalof Plant Physiology. 53: 371-380.

Xue, M.; Malony, M.; Borejsza-Wysocka, E.; Korban, S.S. and Aldwinckle, H.S. (2008): Two Receptor-Like Genes, Vfa1 and Vfa2, Confer Resistance to the Fungal Pathogen Venturia inaequalis Inciting Apple Scab Disease. Molecular Plant-Microbe Interactions. 21 (4): 448-458.

Yancheva, SD.; Golubowicz, S.; Fisher, E.; Lev-Yadun, S.; Flaishman MA. (2003): Auxin type andtimng of applelcation determine the activation of the developmental program during in vitro organogenesis in apple. Plant Sci. 165: 299-309.

Yao, JL.; Cohen, D.; Atkinson, R.; Richardson, K.; Morris, B. (1995): Regeneration of transgenic plants from the commercial apple cultivar 'Royal Gala'. Plant Cell Reports. 14: 407-412.

Zhu LH, Li XY, Ahlman A, Xue ZT, Welander M (2004): The use of mannose as selection agent in transformation of the apple rootstock M.26 via Agrobacterium tumefaciens. Acta Horticulturae. (ISHS) 663: 503-506 